\title{
An Implantable and Controlled Drug-Release Silk Fibroin Nanofibrous Matrix to Advance the Treatment of Solid Tumour Cancers \\ DOI:
}

10.1016/j.biomaterials.2016.06.049

\section{Document Version}

Accepted author manuscript

Link to publication record in Manchester Research Explorer

Citation for published version (APA):

Xie, M., Fan, D., Chen, Y., Zhao, Z., He, X., Li, G., Chen, A., Wu, X., Li, J., Li, Z., Hunt, J. A., Li, Y., \& Lan, P. (2016). An Implantable and Controlled Drug-Release Silk Fibroin Nanofibrous Matrix to Advance the Treatment of Solid Tumour Cancers. Biomaterials, 103, 33-43. https://doi.org/10.1016/j.biomaterials.2016.06.049

\section{Published in:}

Biomaterials

\section{Citing this paper}

Please note that where the full-text provided on Manchester Research Explorer is the Author Accepted Manuscript or Proof version this may differ from the final Published version. If citing, it is advised that you check and use the publisher's definitive version.

\section{General rights}

Copyright and moral rights for the publications made accessible in the Research Explorer are retained by the authors and/or other copyright owners and it is a condition of accessing publications that users recognise and abide by the legal requirements associated with these rights.

\section{Takedown policy}

If you believe that this document breaches copyright please refer to the University of Manchester's Takedown Procedures [http://man.ac.uk/04Y6Bo] or contact uml.scholarlycommunications@manchester.ac.uk providing relevant details, so we can investigate your claim.

\section{OPEN ACCESS}




\section{Accepted Manuscript}

An Implantable and Controlled Drug-Release Silk Fibroin Nanofibrous Matrix to Advance the Treatment of Solid Tumour Cancers

Maobin Xie, Dejun Fan, Yufeng Chen, Zheng Zhao, Xiaowen He, Gang Li, Aizheng Chen, Xiaojian Wu, Jiashen Li, Zhi Li, John A. Hunt, Prof. Yi Li, Prof. Ping Lan

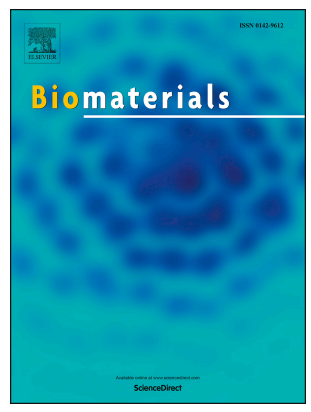

PII:

S0142-9612(16)30309-X

DOI: 10.1016/j.biomaterials.2016.06.049

Reference: JBMT 17588

To appear in: Biomaterials

Received Date: 28 April 2016

Revised Date: 25 May 2016

Accepted Date: 21 June 2016

Please cite this article as: Xie M, Fan D, Chen Y, Zhao Z, He X, Li G, Chen A, Wu X, Li J, Li Z, Hunt JA, Li Y, Lan P, An Implantable and Controlled Drug-Release Silk Fibroin Nanofibrous Matrix to Advance the Treatment of Solid Tumour Cancers, Biomaterials (2016), doi: 10.1016/j.biomaterials.2016.06.049.

This is a PDF file of an unedited manuscript that has been accepted for publication. As a service to our customers we are providing this early version of the manuscript. The manuscript will undergo copyediting, typesetting, and review of the resulting proof before it is published in its final form. Please note that during the production process errors may be discovered which could affect the content, and all legal disclaimers that apply to the journal pertain. 


\title{
An Implantable and Controlled Drug-Release Silk Fibroin Nanofibrous Matrix to Advance the Treatment of Solid Tumour Cancers
}

\author{
Maobin Xie ${ }^{a, b, 1}$, Dejun Fan ${ }^{c, 1}$, Yufeng Chen ${ }^{c}$, Zheng Zhao ${ }^{d}$, Xiaowen He ${ }^{c}$, Gang \\ $\mathrm{Li}^{\mathrm{e}}$, Aizheng Chen ${ }^{\mathrm{f}}$ Xiaojian $\mathrm{Wu}^{\mathrm{c}}$, Jiashen $\mathrm{Li}^{\mathrm{a}}{ }^{\mathrm{b}}$, Zhi Li ${ }^{\mathrm{b}}$, John A. Hunt ${ }^{\mathrm{g}}$, Yi $\mathrm{Li}^{\mathrm{a}}{ }^{\mathrm{b}}$, \\ *, Ping Lan ${ }^{\mathrm{c}}, * *$
}

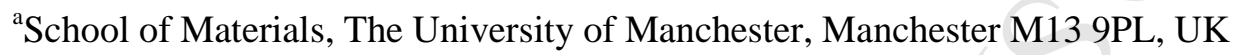

${ }^{\mathrm{b}}$ Institute of Textiles and Clothing, The Hong Kong Polytechnic University, Hung Hom, Hong Kong, China

${ }^{\mathrm{c}}$ Department of Colorectal Surgery, The Sixth Affiliated Hospital of Sun Yat-Sen University, Guangzhou 510655, China

${ }^{\mathrm{d}}$ State Key Lab of Advanced Technology for Materials Synthesis and Processing, Wuhan University of Technology, Wuhan 43000, China

${ }^{\mathrm{e}}$ National Engineering Laboratory for Modern Silk, College of Textile and Clothing Engineering, Soochow University, Suzhou215123, China

${ }^{\mathrm{f}}$ College of Chemical Engineering, Huaqiao University, Xiamen 361021, China

${ }^{\mathrm{g}}$ Institute of Ageing and Chronic Disease, University of Liverpool, Liverpool L7 8TX, UK

${ }^{I}$ These authors contributed to this manuscript equally.

*Correspondence to: Prof. $\mathrm{Yi} \mathrm{Li}$

Tel: +44(0)1613062676, Fax:+44(0)7946418738,E-mail: henry.yili@manchester.ac.uk.

**Co-Correspondence to: Prof. Ping Lan

Tel: +86 (020) 38255801, Fax: +86 (020) 38254221, E-mail: lanping@mail.sysu.edu.cn. 


\section{ABSTRACT}

The development of more effective cancer therapeutic strategies are still critically required. The maximization of the therapeutic effect in combination with avoiding the severe side effects on normal tissues when using chemotherapy drugs is still an urgent problem that requires improvements urgently. Here we provide implantable and controllable drug-release that utilises silk fibroin (SF) as a nanofibrous drug delivery system (DDS) for cancer treatment. A nanofibrous structure with controllable fibre diameter $(<100 \mathrm{~nm})$ was produced. The drug release rate of the SF DDS was controlled by applying a post-treatment process. In vitro anti-cancer (HCT116) results indicated that curcumin (CM)-SF nanofibrous matrix had a superior anti-cancer potential when the concentration was $>5 \mu \mathrm{g} / \mathrm{mL}$. The mechanism could be explained by the cell cycle being held in the S phase. The toxic effect on normal cells (NCM460) was minimized by using a treatment concentration range $(5-20 \mu \mathrm{g} / \mathrm{mL})$. Implantation of this DDS into the tumour site inhibited the growth of solid tumour; this offers an alternative approach for novel cancer therapy.

Keywords: Silk; drug delivery system; curcumin; cancer

\section{Introduction}

Cancer is the leading cause of death in developed countries and the second most life-threatening disease in developing countries. Statistics from 2012 state there were 14.1 million new cases of cancer and 8.2 million of deaths in the world (Cancer Research UK). More than $50 \%$ of patients die of cancers due to the lack of efficient 
treatment. Chemotherapy is the widely and broadly used treatment, which always uses one or more chemotherapeutics to prolong life and or reduce symptoms $[1,2]$. However, current chemotherapeutic drugs have significant side effects on normal healthy cells and tissues if administrated by traditional routes; these are commonly myelosuppression, mucositis and alopecia [3]. Therefore, the major challenge in chemotherapy is to develop drug delivery systems (DDSs) to deliver chemotherapeutic drugs safely and efficaciously without side effects.

Nano structured DDSs which are able to conjugate a drug have the capability to achieve targeted delivery of their content to cancer cells via the enhanced permeability and retention effects [4]. Current nano structured DDSs including nanoparticles, liposomes and micelles are mainly dispensed orally; through this route there are serious existing problems that still cannot be addressed adequately. Such as the lack of tissue specificity [5], inefficient drug release at the tumour site and endosomal entrapment of nanocarriers, all of these significantly reduce efficacy [6].

In order to overcome these barriers, implantable drug delivery (IDD) systems are still being developed. IDDSs originated in the 1960s when silicones were applied to prolong therapeutic efficiency [7], this type of delivery was then recognized as a potential solution to address the issues associated with oral administration of specific therapies. However, little has been reported on the development of nano structured IDDSs, which could offer the potential of high drug loading and better cell uptake efficiency. Here, we supply an implantable, controllable drug-release nanofibrous 
DDS, which can not only protect and deliver chemotherapeutic drugs to the specific site, but can also achieve controllable drug release therefore minimizing side effects.

Silkworm silks are a unique group of fibrous proteins with excellent mechanical strength in fibre form. The clinical use of silk sutures and availability of silkworm silk have encouraged a recent expansion of novel biomaterials from silkworms. Raw silks mainly consist of SF and silk sericin. The unique structure, versatility in processing, biocompatibility, various biomaterial morphologies, the ease of sterilization, thermal stability, surface chemistry for chemical modifications and water solubility features make SF a promising biomaterial for biomedical applications [8-12]. Recently, SF has elicited considerable interests in drug delivery, especially as implantable devices [1, 13]. However, little has been reported on SF-based nanofibrous matrix as IDDS for treatment of solid tumour cancers.

The natural polyphenolic compound curcumin $(\mathrm{CM})$ is highly toxic on a wide range of cancers $[14,15]$. Therefore, in this study CM was used as a drug model and incorporated into SF carriers by solution-enhanced dispersion via supercritical $\mathrm{CO}_{2}$ (SEDS) forming a nanofibrous matrix for topical cancer treatment.

\section{Materials and methods}

\subsection{Materials}

Raw silk fibres of Bombyx mori were purchased from the Jiangsu Wujing China Eastern Silk Market Co. Ltd. (China). Curcumin was purchased from International 
Laboratory (USA). $\mathrm{CO}_{2}$ was supplied by the Hong Kong Specialty Gases Co. Ltd. (Hong Kong). 1,1,1,3,3,3-Hexafluoroisopropanol (HFIP) was from Jinan Huifengda Chemical Co. Ltd. (China). A human colorectal cancer cell line HCT116 and a normal human colon mucosal epithelial cell line NCM460 were obtained from the Cell Bank of the Chinese Academy of Science (Shanghai, China). All other compounds were of analytical purity.

\subsection{Preparation of silk fibroin powder from raw silk fibres}

The raw silk fibres of Bombyx mori were degummed three times to remove enveloped sericin in pressurized water at $120^{\circ} \mathrm{C}$ for $60 \mathrm{~min}$. The degummed SF fibres were then immersed in a blend solution that contained calcium chloride, water, and ethanol with a molar ratio $1: 8: 2$ for $6 \mathrm{~h}$ at $70^{\circ} \mathrm{C}$ until completely dissolved to obtain the regenerated SF solution. Thereafter, the regenerated SF solution was dialyzed against distilled water to remove the neutral salts by semi-permeable cellulose tubing (molecular weight cutoff 12,000-14,000) and to obtain the pure SF solution. Finally, dry SF powders were obtained by spray drying (outlet temperature $\sim 110^{\circ} \mathrm{C}$ ). The samples were kept at $4^{\circ} \mathrm{C}$ for further study.

\subsection{Preparation of curcumin-silk fibroin nanofibrous matrix}

First, CM and SF were mixed (1:19), and then HFIP was added to the required concentration (6\%). After complete dissolution, the blend solution was ready for SEDS (Fig. S1). When the desired pressure and temperature were reached, a steady flow of $\mathrm{CO}_{2}$ (in and out of the vessel) was maintained to modulate the system pressure 
at a constant level. The blend solution was delivered into the high-pressure vessel simultaneously with the supercritical $\mathrm{CO}_{2}$ flow. Enhanced mixing effect between the two flows was achieved using a specially designed nozzle. When the blend solution ran out, the fresh $\mathrm{CO}_{2}$ flow was kept running for $2 \mathrm{~h}$ to completely remove the residual HFIP solvent. The $\mathrm{CO}_{2}$ flow was then stopped, and the high-pressure vessel was slowly depressurized to atmospheric pressure. The material was collected on filters and vacuum dried at $60^{\circ} \mathrm{C}$ for $12 \mathrm{~h}$ and then kept at $4^{\circ} \mathrm{C}$ for further characterizations.

\subsection{Solvent vapour post-treatment}

After moulding into a round shape with radius $1.5 \mathrm{~cm}$, the prepared CM-SF nanofibrous matrices were treated within atmospheres of water vapour, ethanol vapour and $25 \%, 50 \%$ and $75 \%$ ethanol vapour, separately, followed by drying in the hood overnight. Briefly, samples were put into sealed beakers saturated with water vapour, ethanol vapour and $25 \%, 50 \%$ and $75 \%$ ethanol vapour, and moved into the water bath for vapour treatment. The vapour treatment time ranged from 6-12 h, and the temperature was set at the range of $25-37^{\circ} \mathrm{C}$.

\subsection{Surface morphology}

The samples were directly adhered onto an aluminium stub with a thin self-adherent carbon film and then coated with a thin layer of gold. The surface morphology of the samples was observed via field emission scanning electron microscopy (SEM, JEOL, JSM-6490, Japan). 


\subsection{Physicochemical characterizations}

The samples were completely mixed with $\mathrm{KBr}$ and then pressed into a thin tablet. The Fourier transform infrared spectroscopy (FTIR) spectra for the samples were obtained using FTIR Perkin Elmer 1720 (Perkin-Elmer, USA) in transmission mode with the wave number ranging from $4000 \mathrm{~cm}^{-1}$ to $400 \mathrm{~cm}^{-1}$. The crystallinity of samples was evaluated using an X-ray diffractometer (D8 Advance, Bruker AXS, Germany) with $\mathrm{Cu} \mathrm{K} \alpha(\lambda=1.5405 \AA)$ radiation. The measurement was performed in a $2 \theta$ range from $5^{\circ}$ to $45^{\circ}$ with a $0.02^{\circ}$ step size and $10^{\circ} \mathrm{min}^{-1}$ scan speed with a $2 \mathrm{D}$ detector at $40 \mathrm{kV}$ and $40 \mathrm{~mA}$.

\subsection{In vitro drug release study}

Drug release was determined using a modified dialysis bag method. Equal amounts of each sample were dispersed in $5 \mathrm{~mL}$ of phosphate buffer saline (PBS, pH 7.4) and placed in a pre-treated dialysis bag (molecular weight: $12,000-14,000$ Daltons). The bag was then placed into $50 \mathrm{~mL}$ of PBS and incubated in a water bath at $37^{\circ} \mathrm{C}$ and $60 \mathrm{rpm}$. At specified time points, $1 \mathrm{~mL}$ of the solution was removed and centrifuged at 10,000 rpm for 10 minutes. The concentration of the supernatant was determined by UV spectrophotometer at wavelength $410 \mathrm{~nm}$. The cumulative total amount released was calculated in terms of the $\mathrm{CM}$ concentration as a function of time.

\subsection{Cell culture and proliferation}


HCT116 and NCM460 cells were maintained in Roswell Park Memorial Institute

(RPMI) 1640 medium (Gibco, Invitrogen) supplemented with 10\% FBS (Gibco, Invitrogen) and $1 \%$ pen-strep (100 U/ml penicillin and $100 \mu \mathrm{g} / \mathrm{ml}$ streptomycin) (Gibco, Invitrogen) in a $37 \pm 0.2^{\circ} \mathrm{C}$ humidified incubator containing $5 \% \mathrm{CO}_{2}$, respectively. Further, cells were cultured as a monolayer culture and counted using a Cellometer Auto T4 (Nexcelom Bioscience LLC, USA).

\subsection{Cellular uptake study}

The cellular uptake efficiency was evaluated by visualizing HCT116 cells in the presence of CM-SF matrices. Briefly, $5 \times 10^{4} \mathrm{HCT} 116$ cells were seeded onto cover slips (IWAKI, Japan) in 24-well plates overnight to allow cells attach to the cover slips. The samples were then added to co-culture for 0.5 and $6 \mathrm{~h}$. After these time periods cells were washed with $1 \times$ PBS and then fixed with $4 \%$ formaldehyde for 1 $\min .500 \mu \mathrm{L}$ of methanol $\left(-20^{\circ} \mathrm{C}\right)$ was added to completely remove formaldehyde followed by permeabilization with $0.2 \%$ Triton X-100 in PBS for $10 \mathrm{~min}$, and washed again in PBS. Cells were sealed with $10 \%$ BSA. Cell nuclei were stained with $5 \mu \mathrm{L}$ of 4'-6'-diamidino-2-phenylindole (DAPI) for $30 \mathrm{~min}$. Stained cells were finally mounted onto glass slides and observed using confocal laser scanning microscope (CLSM , Leica, TCS SP8).

\subsection{MTS assay}

Both anti-cancer effect of CM-SF nanofibrous matrices on colon cell line HCT116 and cytotoxicity on normal cell line NCM460 were evaluated by MTS assay 
using the CellTiter $96{ }^{\circledR}$ AQueous One Solution Cell Proliferation Assay kit (Promega). Briefly, HCT116 and NCM460 cells were pre-cultivated in the 96 -well plates $\left(5 \times 10^{3}\right.$ cells /well) for $24 \mathrm{~h}$, respectively. The cell medium was replaced by the fresh samples (SF control, CM-DMSO, CM-SF nanofibrous matrix and 5-Fu) in complete DMEM (Dulbecco's modified Eagle's medium) at different concentrations on the next day. After $48 \mathrm{~h}$ of incubation, the culture medium was aspirated and cells were washed with $1 \times$ PBS for three times; $200 \mu \mathrm{L}$ of the MTS solution mixed with $1 \mathrm{~mL}$ fresh serum free medium was then added for another $4 \mathrm{~h}$ of reaction. The absorbance values were measured using a Model 680 Microplate Reader (Model 680, Bio-Rad, CA) at $490 \mathrm{~nm}$. Cell viability was calculated using Eq. (1) below:

Cell viability $(\%)=\frac{\text { Absorbance of test cells }}{\text { Absorbance of control }} \times 10$

Where absorbance of test cells represents the OD490 values of cells treated with different experimental groups; and the absorbance of control cells refers to the OD490 values of non-treated cells in the control groups.

\subsection{Cell cycle and apoptosis measurement}

HCT116 cells $\left(1 \times 10^{6}\right)$ were co-cultured with control, 5-Fu, and CM-SF nanofibrous matrices after ethanol vapour treatment $\left(25^{\circ} \mathrm{C}, 6 \mathrm{~h}\right.$ and $37^{\circ} \mathrm{C}, 12 \mathrm{~h}$, respectively) in the medium, Decanted supernatant and collected cells by trypsinization, then washed and resuspended in PBS. Cells were then fixed with ethanol $\left(70 \%,-20^{\circ} \mathrm{C}\right)$ by vortexing mildly and maintained at $4{ }^{\circ} \mathrm{C}$ for at least $12 \mathrm{~h}$. Thereafter, the cells were pelleted and re-suspended again in $500 \mu \mathrm{L}$ of PBS, then 50 
$\mu \mathrm{L}$ of $7-\mathrm{ADD}$ was added and incubated at room temperature for $30 \mathrm{~min}$ in the dark. The stained samples were then recorded with a BD FACS CatoII flow cytometer (BD Biosciences, USA).

For apoptosis analysis, all the cells $\left(1 \times 10^{6}\right)$ treated with control, 5-Fu, and CM-SF nanofibrous matrices after ethanol vapour treatment $\left(25^{\circ} \mathrm{C}, 6 \mathrm{~h}\right.$ and $37^{\circ} \mathrm{C}, 12 \mathrm{~h}$, respectively) were collected and washed twice with PBS by centrifugation. The cell pellet was re-suspended in $500 \mu \mathrm{L}$ of ice-cold binding buffer. The $5 \mu \mathrm{L}$ of Annexin $\mathrm{V}$-PE and $5 \mu \mathrm{L}$ of 7-ADD solutions were added into the cell suspension by mild vortexing. The samples were then incubated for $5 \mathrm{~min}$ in the dark before flow cytometric analysis. The stained samples were analysed by flow cytometer.

\subsection{Animal preparation}

A total of 15 female BALB/c nude mice (3-5 weeks old) with body weight around $18 \pm 2 \mathrm{~g}$ were supplied by the Laboratory Animal Center of Sun Yat-Sen University (Guangzhou, China). These mice were maintained in a pathogen-free environment $\left(23 \pm 2^{\circ} \mathrm{C}\right.$ and $55 \% \pm 5$ humidity $)$ on a 12 hour light-12 hour dark cycle with food and water supplied ad libitum. Animal care and surgery protocols were approved by the Animal Care Committees of Sun Yat-sen University (Guangzhou, China). All animals were treated appropriately and used in a scientifically valid and ethical manner. To establish CRC allografts for in vivo studies, HCT-116 cells $(5 \times$ $10^{5}$ ) were subcutaneously injected into the back of the BALB/c nude mice. After several days, a tumour with a volume exceeding $100 \mathrm{~mm}^{3}$ formed and the mice were 
randomly separated into 5 groups, three per group according to the volume of tumour calculated by Eq. (2) [16]. Tumour volume and mouse weight change ratio (\%) were calculated using Eq. (3) and (4), respectively. The 5 groups were identified as: (1) and (2) implantation with CM-SF nanofibrous matrix $(10 \mathrm{mg})$ after $25^{\circ} \mathrm{C}, 6 \mathrm{~h}$ and $37^{\circ} \mathrm{C}, 12$ h post-treatment, respectively; (3) intraperitoneal injection with $60 \mathrm{mg} / \mathrm{kg} 5-\mathrm{Fu}$ solution in the first day; (4) Oral injection with identical amount of original CM and (5) implantation with pure SF nanofibrous matrix and as a control. After 12 days observation, all the mice were placed under general anaesthesia by intraperitoneal injection of pentobarbital sodium (30 $\mu \mathrm{g} / \mathrm{g}$ body wt). Fig. 5 (a) shows the operative procedure for the membrane implantation against the tumour. A straight $1 \mathrm{~cm}$ skin incision was made near the tumour, subcutaneous tissue around the tumour was separated so that sufficient space was created for implanting and positioning samples. Finally, the incision was sutured so that the tumour could be treated with the implanted CM-SF nanofibrous matrix directly.

$\mathrm{V}=\mathrm{L} \times \mathrm{W}^{2}$

Tumour volume change ratio $(\%)=\left(\mathrm{V}_{\mathrm{N}} / \mathrm{V}_{1}-1\right) \times 100 \%$

Mouse weight change ratio $(\%)=\left(\mathrm{W}_{\mathrm{N}} / \mathrm{W}_{1}-1\right) \times 100 \%$

Where: $V$ is the volume of tumour, $L$ is the tumour length, $W$ is the tumour width, $V_{l}$ and $V_{N}$ is the tumour volume measured at first day and $N$ days after implantation of coated drug membrane, $W_{l}$ and $W_{N}$ are the mouse weights measured at day 1 and $N$ days after treatment of coated drug membrane. 


\subsection{H\&E staining}

All the tumours separated from the experimental mice were fixed in $10 \%$ formalin solution, embedded in paraffin, sectioned at $5 \mu \mathrm{M}$, and stained with $\mathrm{H} \& \mathrm{E}$ for histopathological examination. Images of each tumour were captured at high magnification $(\times 50$ and $\times 200$ fold $)$ using the Leica DM IRB inverted research microscope (Leica Microsystems, Wetzlar, Germany).

\section{Results and discussion}

\subsection{Surface morphology and chemical structure after ethanol vapour treatment}

Scheme 1 shows the whole experimental design, to construct nano structured SF DDS, SEDS(supplementary Fig. S1). SEDS were modified following previously published protocols $[17,18]$. The surface morphology and fibre diameter are very important factors that affect the physicochemical properties and biomedical functions [19]. Fig. 1 (a) shows that the CM-SF matrix had a nanofibrous structure with fibre diameter $<100 \mathrm{~nm}$. Ethanol vapour treatment was employed to control drug release as shown in Fig. 1. The temperature was set at $25-37^{\circ} \mathrm{C}$, and the treatment time was 6-12 h. The surface morphology of sample after ethanol vapour treatment was maintained (Fig. 1, (b));

The chemical structure and composition of CM-SF nanofibrous matrices after ethanol vapour treatment shown in Fig. 1, (c). As can be seen, there were no significant changes in the amide II and amide III regions of SF after ethanol vapour 
treatments; however, the amide I region became more predominant with increased treatment time and temperature, which indicated that the silk I structure ( $\alpha$-helix and/or random coil conformation) became more stable (water-insoluble) when exposed to ethanol vapour with higher temperature and longer treatment time.

\subsection{In vitro drug release after ethanol vapour treatment}

However, the drug release profiles of CM-SF nanofibrous matrices after ethanol vapour treatments were different, that is, the release rate became slower with increased treatment time and temperature (Fig. 1, (d) and (e)). The no treated group showed a higher release rate than the treated groups within $2 \mathrm{~h}$, followed by a sharp decrease after two weeks. On the other hand, the ethanol vapour treated groups remained at a more stable release rate during the two-week experimental period, which suggested that ethanol vapour treated CM-SF nanofibrous matrices have long-term controllable drug release potential. The results are in agreement with previous studies on water-stable silk films with reduced $\beta$-sheet content [20]. Controlled release of $\mathrm{CM}$ from SF-based nanofibrous matrices without inducing $\beta$-sheet transform could be explained by the formation of a stable silk I structure (Fig. 1, (b) and (c)). Thus, CM-SF nanofibrous matrices treated by ethanol vapour could maintain their stable silk I structure (water-stable) and a long-term release rate without inducing $\beta$-sheet structural content.

\subsection{Interactions of curcumin-silk nanofibrous matrix between cancer cells}

To investigate the interaction between CM-SF nanofibrous matrices and cancer 
cells, qualitative intracellular uptake assays were performed in Fig. 2, (a), fluorescence images of the cancer cells (HCT116) treated with different groups (IC50 of CM: $\sim 5 \mu \mathrm{g} / \mathrm{mL}$ ) for $0.5 \mathrm{~h}$ and $6 \mathrm{~h}$ were observed. The control group did not exhibit any green fluorescence at the measured time. In the CM-SF no treatment group, several slightly green fluorescent dots were observed after $0.5 \mathrm{~h}$ of treatment and the intensity of the green fluorescence increased after $6 \mathrm{~h}$ of treatment. By contrast, a lot of bright green dots presented in CM-SF nanofibrous matrices after post-treatment after 0.5 and $6 \mathrm{~h}$ co-culture compared to the no treatment group. Moreover, the $37^{\circ} \mathrm{C}$, $12 \mathrm{~h}$ treatment group displayed more, brighter dots than the $25^{\circ} \mathrm{C}, 6 \mathrm{~h}$ treatment group. This result indicated that CM-SF nanofibrous matrices after $37^{\circ} \mathrm{C}, 12 \mathrm{~h}$ of treatment had better interaction with cancer cells and CM could rapidly accumulate in the nuclei compared to the $25^{\circ} \mathrm{C}, 6 \mathrm{~h}$ treatment and no treatment groups. The reason could be the more stable silk I structure (water-stable) in the $37^{\circ} \mathrm{C}, 12 \mathrm{~h}$ treatment group. As reported by Hyoung-Joon Jin et al [20], a more stale silk I structure in silk films favored initial cell-biomaterial interactions. Our observations were in agreement with a previous study on SF hydrogels, which suggested that the nanofibrous structure of SF-derived materials is important for cell attachment and cell-matrix interactions [21]. Thus, we assumed that a more stable silk I structure of SF could ensure CM-SF maintained nanofibrous structure stable for a long time in water, allowing a stronger initial cell-biomatierial interactions. Another possible mechanism of the enhanced cell uptake efficiency are illustrated in Fig.2, (b), that is, CM could be transported into cancer cells by endocytosis [22]. In a summary, we assumed that ethanol vapour 
treatment facilitated formation of stable silk I structure of SF, which could improve the transportation efficiency of CM into cancer cells by endocytosis.

\subsection{In vitro anti-cancer efficiency of curcumin-silk fibroin nanofibrous matrix}

In vitro anti-cancer effect (dose-depend) of CM-SF nanofibrous matrices was shown Fig. 3, (a). 5-Fu displayed a dose-dependent anti-cancer effect from 0.625-20 $\mu \mathrm{g} / \mathrm{mL}$. The CM-SF nanofibrous matrices and CM-DMSO groups exhibited little inhibitory effects $<1.25 \mu \mathrm{g} / \mathrm{mL}$, and their anti-cancer effects increased sharply when the concentration reached $5 \mu \mathrm{g} / \mathrm{mL}$, which confirmed that $\mathrm{CM}$ is a highly dose-sensitive medicine. Furthermore, both CM-SF nanofibrous matrices and CM-DMSO exhibited a higher anti-cancer effect than 5-Fu at a concentration $>10$ $\mu \mathrm{g} / \mathrm{mL}$. In contrast, the SF control displayed no decrease in cell viability at all concentrations. The results indicated that CM-SF nanofibrous matrices have superior anti-cancer potential when the concentration is $>5 \mu \mathrm{g} / \mathrm{mL}$.

The evaluation of time-depend in vitro anti-cancer effect of CM-SF nanofibrous matrices with or without ethanol vapour treatment is shown in Fig. 3, (c). Cancer cells were treated with different groups at their IC50 concentration for 6 days. As can be seen, $\mathrm{CM}$ in the medium group exhibited a lower anti-cancer effect than $5-\mathrm{Fu}$ and CM-SF nanofibrous matrices (no treatment) groups, which is mainly due to the water insolubility of CM. Meanwhile, no treated CM-SF nanofibrous matrix group showed lower anti-cancer effect than the post-treated groups during all experimental period, which is owing to the lower cell uptake efficiency of no treated CM-SF nanofibrous 
matrix (Fig. (2)). It was also found that the cell viability of HCT116 treated with CM-SF nanofibrous matrices after $25^{\circ} \mathrm{C}, 6 \mathrm{~h}$ of treatment and $37^{\circ} \mathrm{C}, 12 \mathrm{~h}$ of treatment was similar on day 2. However, a significant difference was obtained on day 4 and day 6 , that is, the $37^{\circ} \mathrm{C}, 12 \mathrm{~h}$ treatment group exhibited a more stable anti-cancer effect compared to the $25^{\circ} \mathrm{C}, 6 \mathrm{~h}$ treatment group, which is due to the better controlled release ability of $\mathrm{CM}$ from $\mathrm{CM}-\mathrm{SF}$ nanofibrous matrices after $37^{\circ} \mathrm{C}, 12 \mathrm{~h}$ of ethanol vapour treatment. Furthermore, the pure SF control group exhibited negligible reduction in cell viability during the test period. In summary, CM-SF nanofibrous matrices after ethanol vapour treatment (especially after $37^{\circ} \mathrm{C}, 12 \mathrm{~h}$ of treatment) possessed a long-term stable anti-cancer effect that was mainly caused by continued delivery of CM to the cells.

\subsection{Cytotoxicity of curcumin-silk fibroin nanofibrous matrix}

The cytotoxicity of CM-SF nanofibrous matrices on normal cells (NCM460) at concentrations ranging from $2.5-40 \mu \mathrm{g} / \mathrm{mL}$ was shown in Fig. 3, (b). It was found that 5-Fu had significant toxicity $(\sim 78 \%)$ from $2.5 \mu \mathrm{g} / \mathrm{mL}$, and this toxic effect increased with increasing concentration. In contrast, both CM-DMSO and CM-SF nanofibrous matrix groups exhibited no toxicity at $<5 \mu \mathrm{g} / \mathrm{mL}$. However, a sharp increase in cytotoxicity was observed in the CM-DMSO group ( 48\%) at $10 \mu \mathrm{g} / \mathrm{mL}$, but no cytotoxicity effect was found in the CM-SF nanofibrous matrix group until $40 \mu \mathrm{g} / \mathrm{mL}$, suggesting that entrapment of $\mathrm{CM}$ in $\mathrm{SF}$ nanofibrous matrix could reduce the toxic effect within a smart treatment concentration range (STCR) $(5-20 \mu \mathrm{g} / \mathrm{mL})($ Fig. 3, (e)). 
STCR could be explained by the facts that (1) CM has a higher toxic effect on colon cancer cells than normal cells; (2) the entrapped CM is slowly released from the SF nanofibrous matrix with better control of $\mathrm{CM}$ concentration in the surrounding environment, which would result in higher uptake by cancer cells than normal cells due to difference in their metabolisms, thus reducing the adverse side-effects on normal cells. On the other hand, both the increased cell uptake ability (Fig. 2) and enhanced permeability and retention (EPR) effect of CM-SF nanofibrous matrix contribute to the enhanced anti-cancer effect. The pure SF control group displayed no toxicity through the test concentration range.

Evaluations of the time-dependent cytotoxicity on normal cells (NCM460) were also performed to study the long-term in vitro toxic effect of CM-SF nanofibrous matrices with or without ethanol vapour post-treatment (Fig. 3, (d)). As can be seen, 5-Fu at IC50 exhibited a toxic effect from day 0-6. On the other hand, the pure SF control and CM-SF nanofibrous matrices with or without post-treatment exhibited no toxic effect within the whole experimental period. In conclusion, incorporating CM into SF nanofibrous matrix after ethanol vapour treatment could have a smart treatment potential in cancer therapy.

\subsection{Cell cycle arrest by curcumin-silk fibroin nanofibrous matrix}

To further investigate the mechanism for the observed inhibition of colon cancer cells by CM-SF nanofibrous matrices, We studied the cell cycle of HCT116 cells treated with different groups at IC50 concentration for 24 and 48 h (Fig. 4, (a) and (c)). 
Cancer cells treated with the 5-Fu group displayed high populations $(\sim 47 \%)$ of cells in the $\mathrm{S}$ phase at $24 \mathrm{~h}$, which meant that 5-Fu caused significant arrest of cells in the $\mathrm{S}$ phase. However, this effect was decreased ( 43\%) for co-cultures at $48 \mathrm{~h}$. This may have been due to the decomposition of 5-Fu. Both the $25^{\circ} \mathrm{C}, 6 \mathrm{~h}$ treated and $37^{\circ} \mathrm{C}, 12$ $\mathrm{h}$ treated CM-SF nanofibrous matrix groups presented an increased percentage of cells in the S phase ( $\sim 5 \%$ and $\sim 66 \%$, respectively) from 24 to $48 \mathrm{~h}$ compared to the control group ( $39 \%$ for $48 \mathrm{~h}$ ), which was due to the continued release of CM from the matrices. Overall, the continuous anti-cancer effect of CM-SF nanofibrous matrices originated from increased efficacy in arresting cancer cells at the $\mathrm{S}$ phase of the cell cycle. Our results are agreement with a previous study on human mantle cell lymphoma (MCL), which suggested that CM inhibits proliferation of MCL through G1/S phase arrest [23].

\subsection{Induction of cell apoptosis by curcumin-silk fibroin nanofibrous matrix}

Previous research has reported that $\mathrm{CM}$ is responsible for inducing apoptosis in a variety of cancers including breast, lung, pancreatic and colon [24-26]. To study the potential of CM-SF nanofibrous matrices to induce apoptosis in colon cancer cells (HCT116), cells were treated with the control, 5-Fu and CM-SF nanofibrous matrices $\left(25^{\circ} \mathrm{C}, 6 \mathrm{~h}\right.$ and $37^{\circ} \mathrm{C}, 12 \mathrm{~h}$ of treatment, respectively) at IC50 concentration for $24 \mathrm{~h}$ and $48 \mathrm{~h}$ (Fig. 4, (b) and (d)). The 5-Fu group exhibited a similar percentage $(\sim 16 \%)$ of apoptotic cells at $24 \mathrm{~h}$ and $48 \mathrm{~h}$ experimental points. On the other hand, cancer cells treated with CM-SF nanofibrous matrices after ethanol vapour treatment exhibited a 
higher percentage of apoptotic cells compared to the 5-Fu and control groups for the whole experimental period. Moreover, the $37^{\circ} \mathrm{C}, 12 \mathrm{~h}$ treatment group exhibited better apoptotic cell induction than the $25^{\circ} \mathrm{C}, 6 \mathrm{~h}$ treatment group, which was mainly due to the improved cellular uptake.

In summary, the results demonstrated that CM-SF nanofibrous matrices after ethanol vapour treatment have higher apoptotic cell induction which was responsible for the higher anti-cancer effect. Our results were similar to a previous study on CM-loaded polymeric micelles for the treatment of colon cancers [27], which suggested that the mechanism of inhibition of growth of colon cells was due to increased apoptosis associated with cell cycle arrest. The mechanism of cell apoptosis induction of CM could be through the inhibition of key anti-apoptotic proteins, Mcl-1, Bcl-xL which cause the induction of PARP cleavage [28].

\subsection{In vivo solid tumour treatment}

Implantation of CM-SF nanofibrous matrices for the treatment of solid tumours in vivo was performed, Fig. 5, (a) showed the implantation process. (Supplementary Fig. S6 showed the images of implanted CM-SF nanofibrous remained in the tumour site after 12 days) Tumour volume and body weight of all treated mice were recorded every two days, up to the end of the experiment at 12 days. Fig. 5, (b) showed the tumour volume change ratio. The results showed that the tumour volume in the SF control, original $\mathrm{CM}$ and 5-Fu groups increased to at least 2 times by 12 days. On the other hand, The CM-SF nanofibrous matrix groups $\left(25^{\circ} \mathrm{C}, 6 \mathrm{~h}\right.$ and $37^{\circ} \mathrm{C}, 12 \mathrm{~h}$ treated $)$ 
showed only a small increase in the tumour volume. This was indicative that the CM-SF nanofibrous matrices had a more significant anti-tumour effect than the other groups ( i.e. 5-Fu group injected intraperitoneally at LD50, original CM group orally administrated and the SF control group). Fig. 5, (d and e) confirmed that the implantation of CM-SF nanofibrous matrices could treat tumours more effectively than other administration routes. Especially, the $37^{\circ} \mathrm{C}, 12 \mathrm{~h}$ treated group which had the lightest and smallest tumours; this was due to their slower drug release and better intracellular uptake effect. There is no statistical difference in body weight when compare these groups (Fig. 5, (c)), and the body weight of all groups decreased a little during the experimental period, so it is believed that the tumour growth in the mice is a main reason that causing the weight loss. Meanwhile, the implantation surgery could be a possible reason for decrease in body weight of post-treated CM-SF nanofibrous groups. In conclusion, CM-SF nanofibrous matrices would not induce obvious side effects. This advantage indicated that the CM-SF nanofibrous matrices as implantable devices could treat tumours directly showing a better therapeutic efficacy and furthermore, would protect patients from side effects.

\subsection{H\&E stain analysis}

To study the anti-cancer mechanism, histological analysis of tumour sections was performed at the $12^{\text {th }}$ day. All the tumours obtained from the experimental mice were H\&E stained and observed under the optical microscope. The representative areas were captured (above: $\times 50$; beneath: $\times 200$ ). As shown in Fig. 5, (f), tissue necrosis 
was frequently observed for the SF control group, then gradually decreased in the CM and 5-Fu groups to rarely in the CM-SF nanofibrous matrices groups (barely seen in the $37^{\circ} \mathrm{C}, 12 \mathrm{~h}$ treated group). The tissue necrosis was attributed to the rapid growth of the tumour and ischemia in parts of the tumour [29]. The different anti-cancer capability resulted from different levels of apoptosis. As seen in SF control, original $\mathrm{CM}$ and 5-Fu at LD50 groups, tumours grew rapidly and necrosis was observed in the ischemic areas, but few tumour cells were apoptotic. CM-SF nanofibrous matrices reduced the rate of growth tumours markedly; tissues had high apoptotic to necrotic ratios. This result corresponded to the previous in vitro cell apoptosis analysis (Fig. 4). As a result of direct contact with tumour tissue, CM-SF nanofibrous matrices presented the slowest growth of tumours. The tumour volume and tumour weight were smaller and lower than other groups, fewer necrotic but more apoptotic cells were observed. In a summary, this result suggested that implantation of CM-SF nanofibrous matrix provided superior induction of apoptosis in vivo.

\section{Conclusions}

In conclusion, CM-SF nanofibrous matrices had improved intracellular uptake, this resulted in an enhanced anti-cancer effect. The mechanism could be explained by cell cycle arrest in the $\mathrm{S}$ phase in association with inducing apoptosis in tumour cells. Importantly, CM-SF nanofibrous matrices reduced cytotoxicity at a smart treatment concentration range $(5-20 \mu \mathrm{g} / \mathrm{mL})$ due to controlled release properties. Moreover, implantation of CM-SF nanofibrous matrices for topical treatment of solid tumour 
showed the smallest tumour volume and lightest tumour weight. It was concluded that implantation of CM-SF nanofibrous matrices have smart tumour treatment potential, offering an alternative method for novel cancer therapy.

\section{Acknowledgements}

We would like to thank the Hong Kong Research Grant Council and the Hong Kong Polytechnic University for providing funding support to this research through projects PolyU5242/09E and G-YM63. Also, we would like to thank the support of University of Manchester through projects with project codes AA14512 and AA01906. Finally, we would like to thank the support of Guangdong Provincial Department of Science and Technology, China through project 2012B091000143 and Guangdong Department of Finance, China through project 2014SC111.

\section{References}

[1] S.W. Hwang, H. Tao, D.H. Kim, H. Cheng, J.K. Song, E. Rill, et al. A physically transient form of silicon electronics, Science. 337 (2012) 1640-1644.

[2] C. Li, A targeted approach to cancer imaging and therapy, Nat Mater. 13 (2014) 110-115.

[3] L. Sanche, Cancer treatment: low-energy electron therapy, Nat Mater. 14 (2015) $861-863$.

[4] T. Kaasgaard, T.L. Andresen, Liposomal cancer therapy: exploiting tumor characteristics, Expert Opin Drug Deliv. 7 (2010) 225-243.

[5] L.W. Kleiner, J.C. Wright, Y. Wang, Evolution of implantable and insertable drug 
delivery systems, J Control Release. 181 (2014) 1-10.

[6] M. Kanamala, W.R. Wilson, M. Yang, B.D. Palmer, Z. Wu, Mechanisms and biomaterials in pH-responsive tumour targeted drug delivery: a review, Biomaterials. 85 (2016) 152-167.

[7] J. Folkman, D.M. Long, The use of silicone rubber as a carrier for prolonged drug therapy, J Surg Res. 4 (1964) 139-142.

[8] F.G. Omenetto, D.L. Kaplan, New opportunities for an ancient material, Science. 329 (2010) 528-531.

[9] Z. Zhao, Y. Li, M.B. Xie, Silk fibroin-based nanoparticles for drug delivery, Int J Mol Sci. 16 (2015) 4880-4903.

[10] M.B. Xie, Y. Li, J.S. Li, A.Z. Chen, Z. Zhao, G. Li, Biomedical applications of silk fibroin, Text Bioeng Inform S. Vols 1 and 2 (2014) 207-218.

[11] M.S. Mannoor, H. Tao, J.D. Clayton, A. Sengupta, D.L. Kaplan, R.R. Naik, et al. Graphene-based wireless bacteria detection on tooth enamel, Nat Commun. 3 (2012) 763.

[12] B. Zhu, H. Wang, W.R. Leow, Y. Cai, X.J. Loh, M.Y. Han, et al. Silk fibroin for flexible electronic devices, Adv Materials. 2015. (DOI: 10.1002/ADMA.201504276)

[13] K. Tsioris, W.K. Raja, E.M. Pritchard, B. Panilaitis, D.L. Kaplan, F.G. Omenetto, Fabrication of silk microneedles for controlled-release drug delivery, Adv Funct Mater. 22 (2012) 330-335.

[14] M.B. Xie, Y. Li, Z. Zhao, A.Z. Chen, J.S. Li, J.Y. Hu, et al. Solubility 
enhancement of curcumin via supercritical $\mathrm{CO} 2$ based silk fibroin carrier, J Supercrit Fluid. 103 (2015) 1-9.

[15] O. Naksuriya, S. Okonogi, R.M. Schiffelers, W.E. Hennink, Curcumin nanoformulations: a review of pharmaceutical properties and preclinical studies and clinical data related to cancer treatment, Biomaterials. 35 (2014) 3365-3383.

[16] G. Li, Y.F. Chen, J. Hu, X.J. Wu, J.Y. Hu, X.W. He, et al. A 5-fluorouracil-loaded polydioxanone weft-knitted stent for the treatment of colorectal cancer, Biomaterials. 34 (2013) 9451-9461.

[17] A.Z. Chen, G.Y. Wang, S.B. Wang, J.G. Feng, Y.G. Liu, W. Zheng, Preparation of ibuprofen-loaded poly-(methyl vinyl ether-co-maleic anhydride) nanoparticles by solution-enhanced dispersion by supercritical CO2, J Fiber Bioeng Inform. 5 (2015) 309-320.

[18] Z. Zhao, M.B. Xie, Y. Li, A.Z. Chen, G. Li, J. Zhang, et al., Formation of curcumin nanoparticles via solution-enhanced dispersion by supercritical $\mathrm{CO} 2$, Int J Nanomed. 10 (2015) 3171-3181.

[19] M.B. Xie, D.J. Fan, Z. Zhao, Z. Li, G. Li, Y.F. Chen, et al., Nano-curcumin prepared via supercritical: improved anti-bacterial, anti-oxidant and anti-cancer efficacy, Int J Pharm. 496 (2015) 732-740.

[20] H.J. Jin, J. Park, V. Karageorgiou, U.J. Kim, R. Valluzzi, D.L. Kaplan, Water-stable silk films with reduced beta-sheet content, Adv Funct Mater. 15 (2005) 1241-1247.

[21] M. Ribeiro, M.A. de Moraes, M.M. Beppu, M.P. Garcia, M.H. Fernandes, F.J. 
Monteiro, et al., Development of silk fibroin/nanohydroxyapatite composite hydrogels for bone tissue engineering, Eur Polym J. 67 (2015) 66-77.

[22] C. He, Y. Hu, L. Yin, C. Tang, C. Yin, Effects of particle size and surface charge on cellular uptake and biodistribution of polymeric nanoparticles, Biomaterials. 31 (2010) 3657-3666.

[23] S. Shishodia, H.M. Amin, R. Lai, B.B. Aggarwal, Curcumin (diferuloylmethane) inhibits constitutive NF-kappa B activation, induces G1/S arrest, suppresses proliferation, and induces apoptosis in mantle cell lymphoma, Biochem Pharmacol. 70 (2005) 700-713.

[24] B.B. Aggarwal, S. Shishodia, Y. Takada, S. Banerjee, R.A. Newman, C.E. Bueso-Ramos, et al., Curcumin suppresses the paclitaxel-induced nuclear factor-kappa B pathway in breast cancer cells and inhibits lung metastasis of human breast cancer in nude mice. Clin Cancer Res. 11 (2005) 7490-7498.

[25] M.M. Yallapu, S. Khan, D.M. Maher, M.C. Ebeling, V. Sundram, N. Chauhan, et al., Anti-cancer activity of curcumin loaded nanoparticles in prostate cancer, Biomaterials. 35 (2014) 8635-8648.

[26] T. Kawamori, R. Lubet, V.E. Steele, G.J. Kelloff, R.B. Kaskey, C.V. Rao, et al., Chemopreventive effect of curcumin, a naturally occurring anti-inflammatory agent, during the promotion/progression stages of colon cancer, Cancer Res. 59 (1999) 597-601.

[27] X. Yang, Z.J. Li, N. Wang, L. Li, L.J. Song, T. He, et al., Curcumin-encapsulated polymeric micelles suppress the development of colon cancer in vitro and in vivo, 
Sci Rep-Uk. 5 (2015) 10322.

[28] M.M. Yallapu, S. Khan, D.M. Maher, M.C. Ebeling, V. Sundram, N. Chauhan, et al., Anti-cancer activity of curcumin loaded nanoparticles in prostate cancer, Biomaterials. 35 (2014) 8635-8648.

[29] J. Wang, G. Yang, X. Guo, Z.M. Tang, Z.D. Zhong, S.B. Zhou, Redox-responsive polyanhydride micelles for cancer therapy, Biomaterials. 35 (2014) 3080-3090. 


\section{Figures}
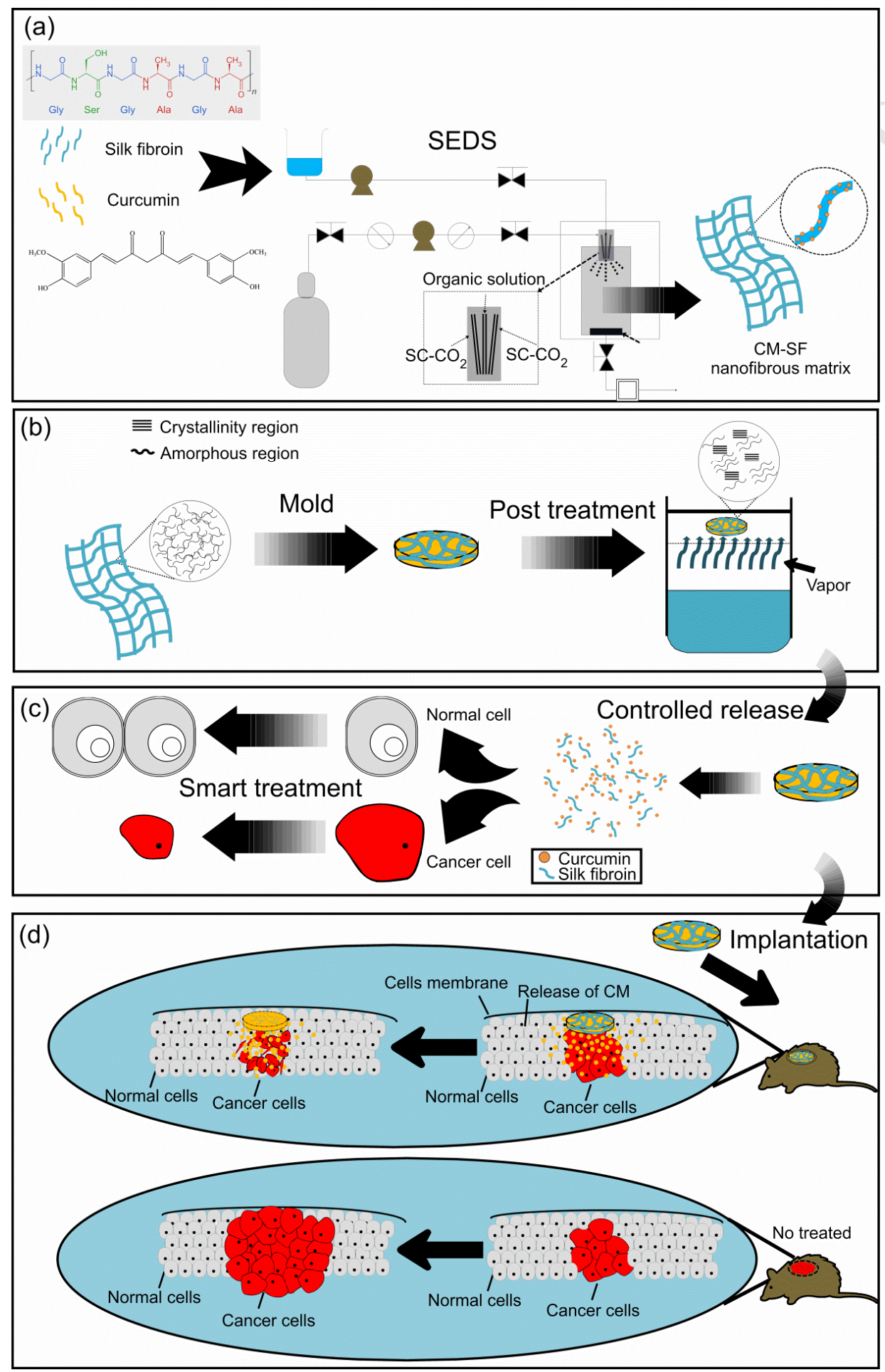

Scheme 1. 


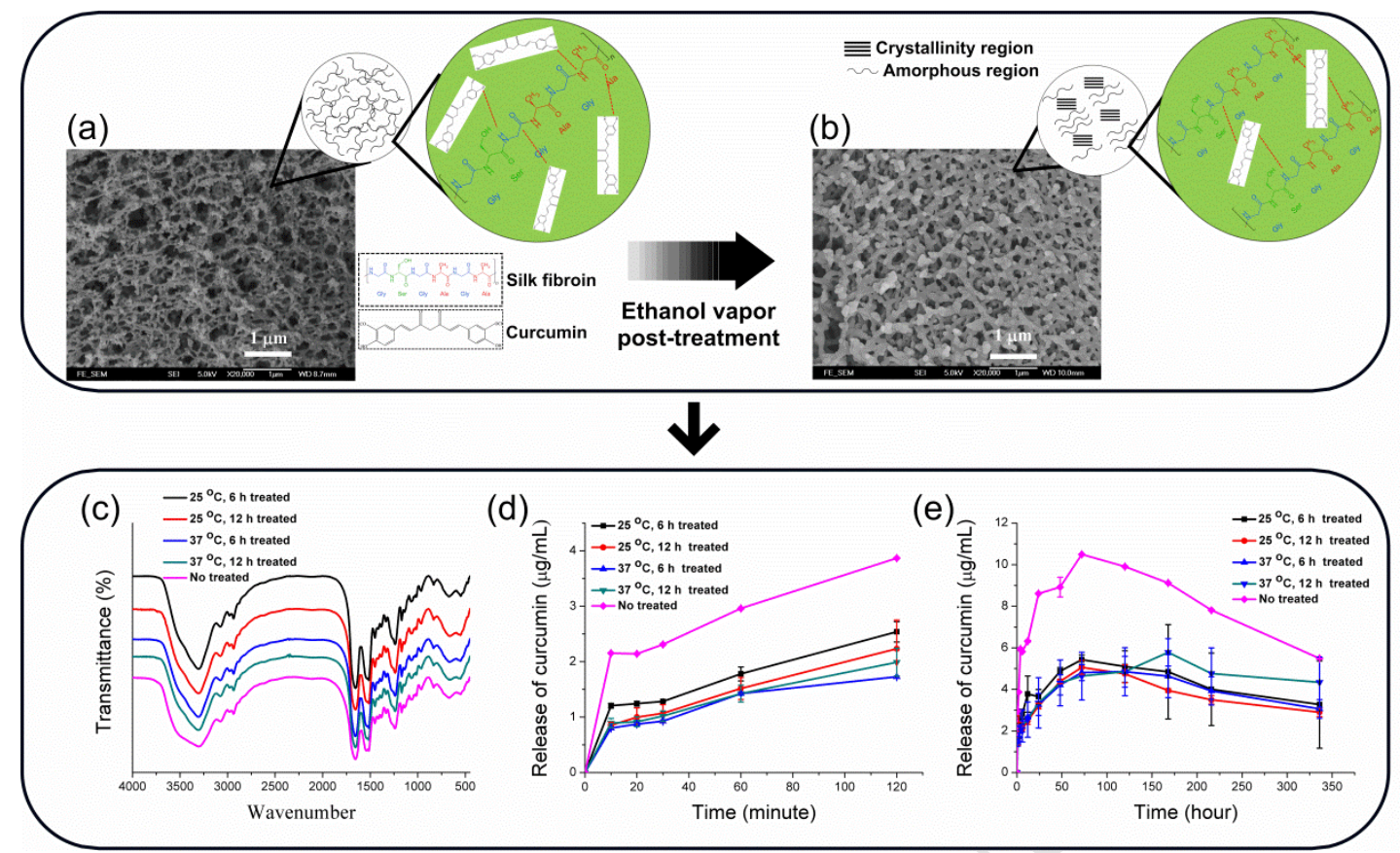

Fig. 1

(a)

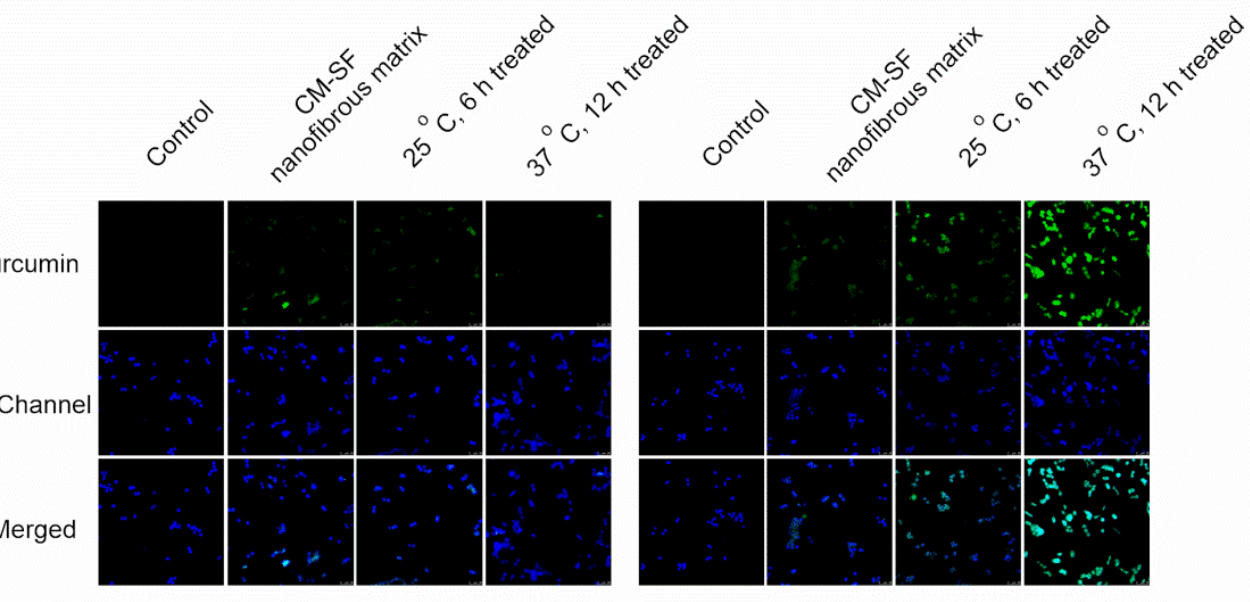

$0.5 \mathrm{~h}$

$6 \mathrm{~h}$

(b)

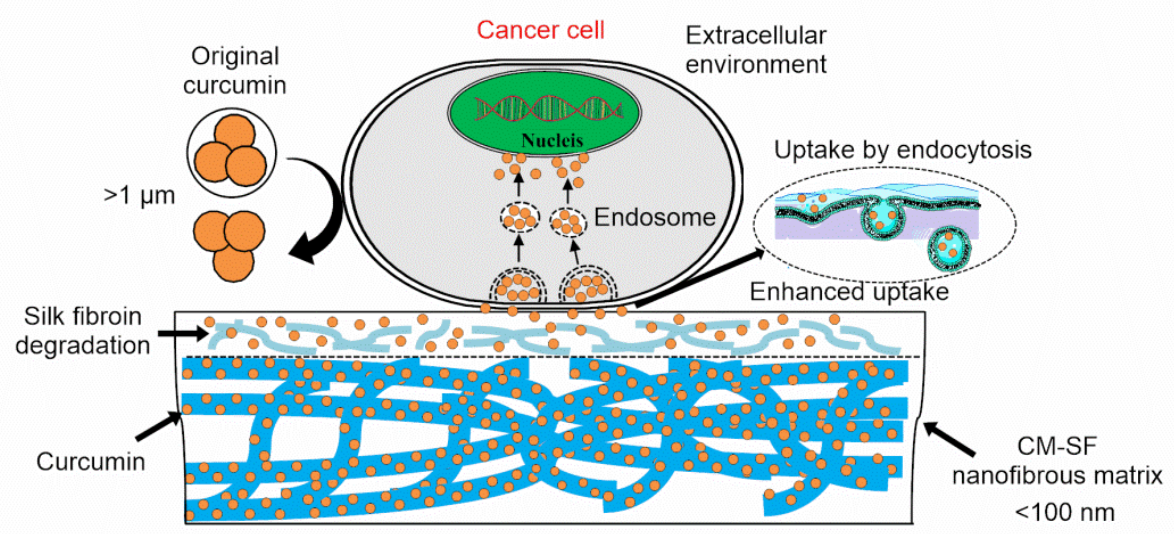

Fig. 2 
(a)

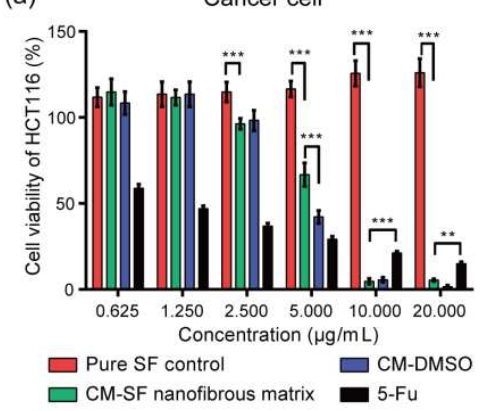

(c)

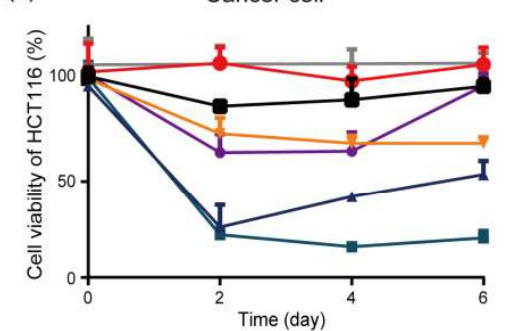

$\rightarrow$ Control $\rightarrow$ CM-SF no treated

- Pure SF control — CM-SF-25 C, $6 \mathrm{~h}$ treated

$\rightarrow \mathrm{CM}$ in medium $\rightarrow \mathrm{CM}-\mathrm{SF}-37 \mathrm{C}, 12 \mathrm{~h}$ treated

$\rightarrow 5$ - Fu

(e)

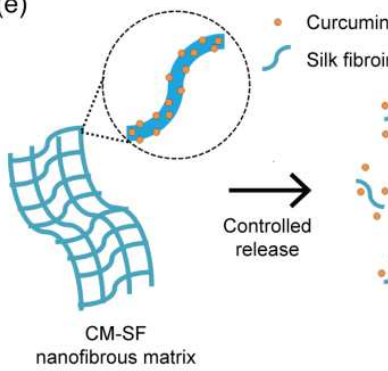

(b) Normal cell

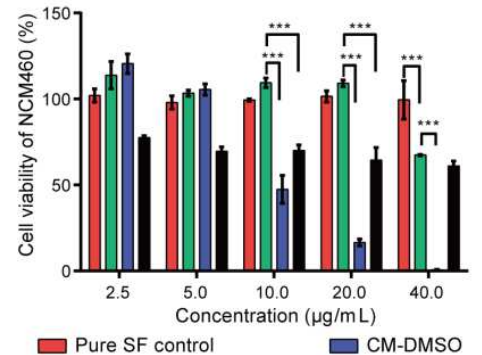

$\square \mathrm{CM}-\mathrm{SF}$ nanofibrous matrix 5-Fu

(d)

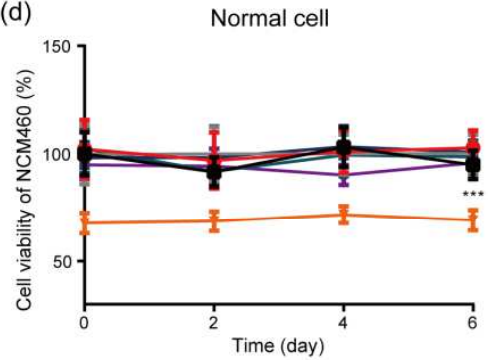

$\rightarrow$ Control $\rightarrow$ CM-SF no treated

- Pure SF control — CM-SF-25 C, $6 \mathrm{~h}$ treated

- $\mathrm{CM}$ in medium $\quad-\mathrm{CM}-\mathrm{SF}-37 \mathrm{C}, 12 \mathrm{~h}$ treated

- 5 - Fu
No inhibition

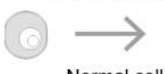

Normal cell

Smart treatment concentration range (STCR) $(5 \sim 20 \mu \mathrm{g} / \mathrm{mL})$

Strong inhibition

Fig. 3 
(a)

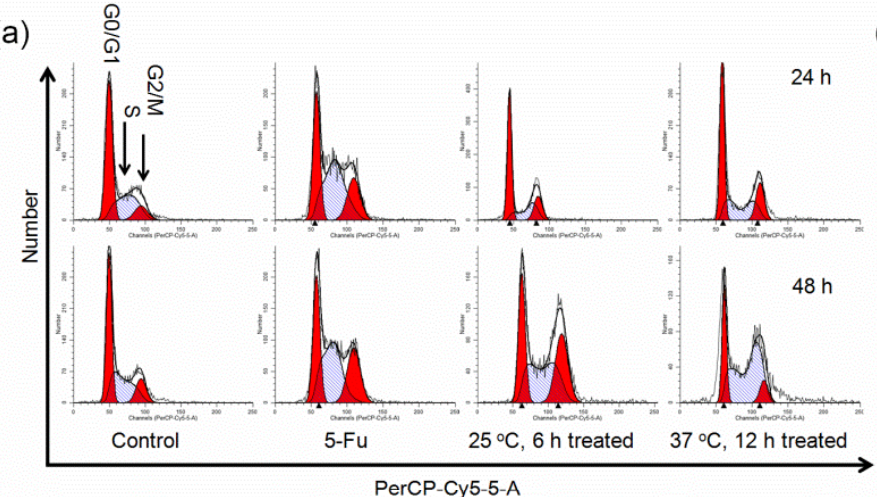

(b)

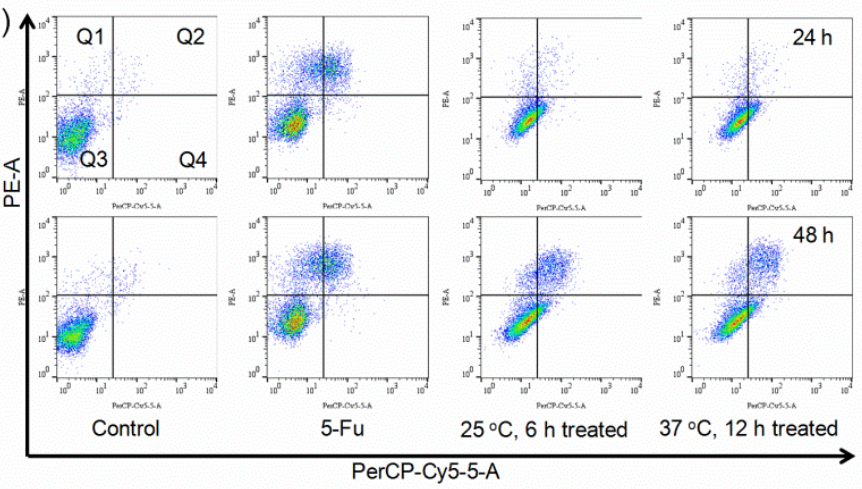

(c)

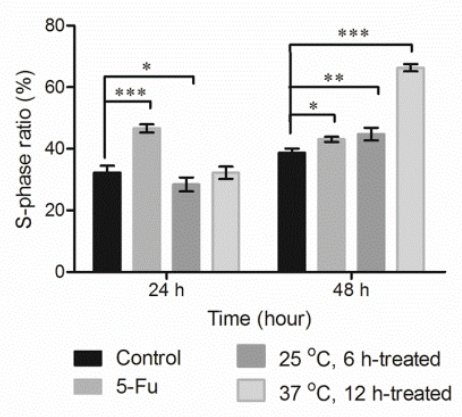

(d)

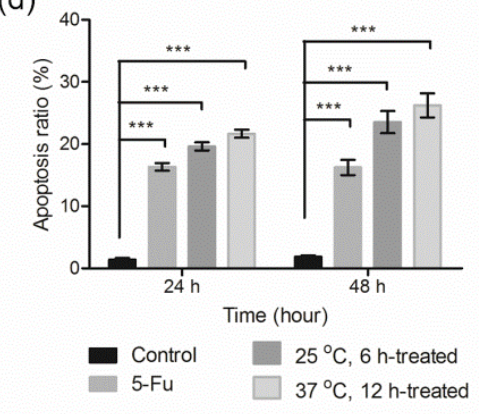

Fig. 4 
(a)

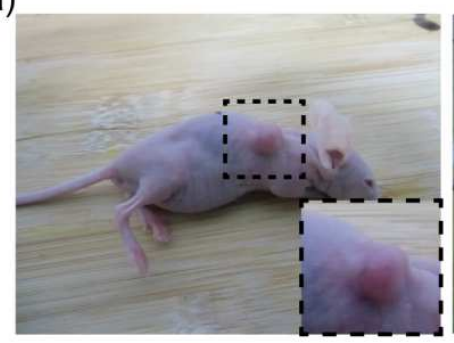

(b)

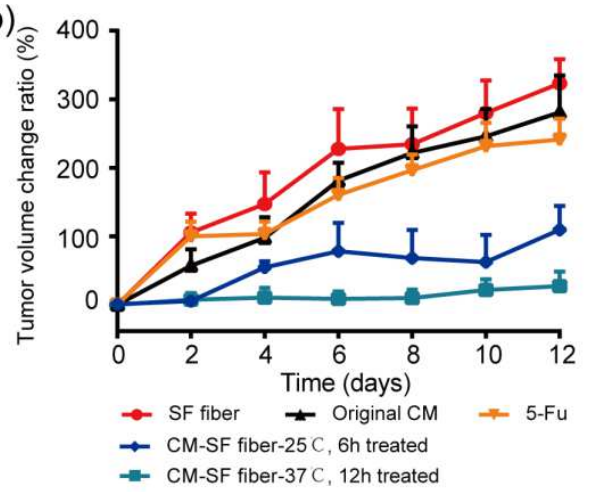

(d)

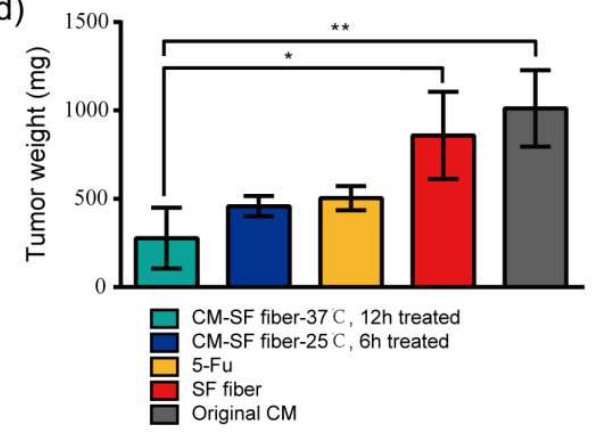

(e)

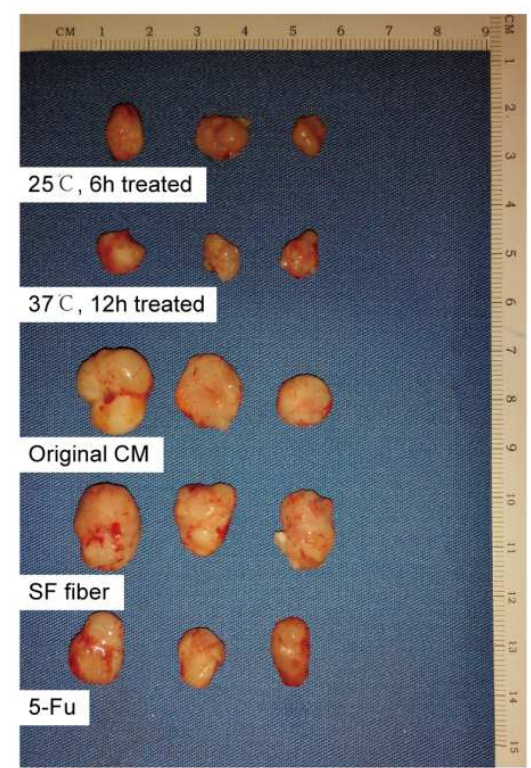

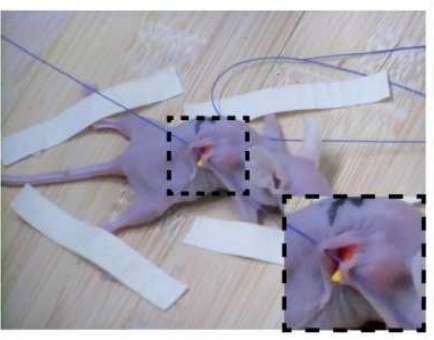

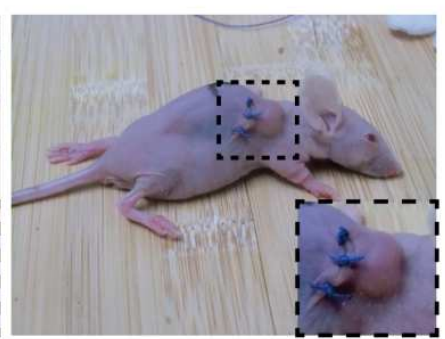

(c)

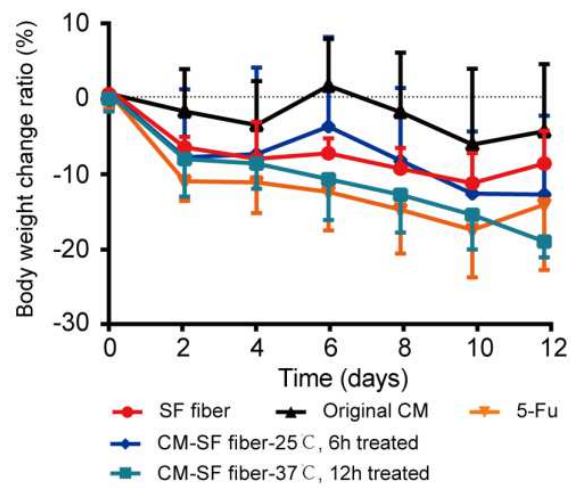

(f)

$\times 50$

$\times 200$
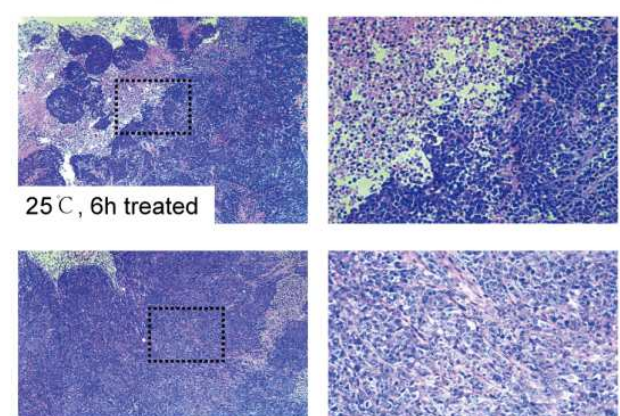

$37 \mathrm{C}, 12 \mathrm{~h}$ treated
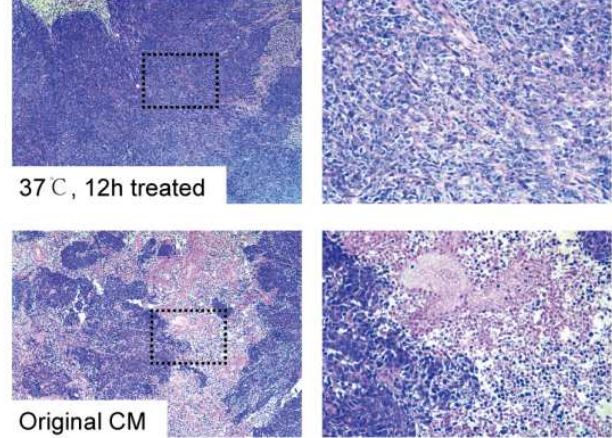

Original CM
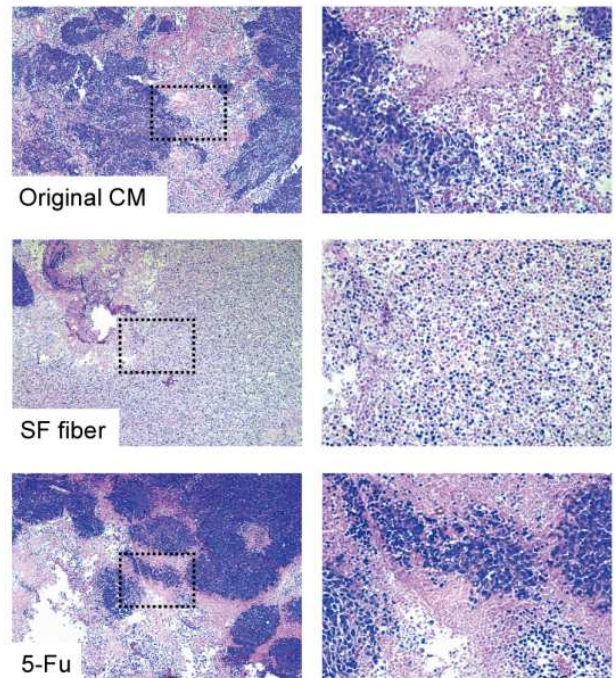

Fig. 5 


\section{Figure captions}

Scheme 1. (a) Diagram presents the preparation of CM-SF nanofibrous matrix via SEDS; (b) schematic of ethanol vapour post-treatment and proposed chemical structure; (c) differential treatment on cancer cells and normal cells in a controlled drug release fashion achieved by ethanol vapour post-treatments; (d) treatment of solid tumour cancers through implantation of post-treated CM-SF nanofibrous matrix into tumour sites; post-treated CM-SF nanofibrous matrix directly attached to the solid tumours and incorporated CM was continuously released into cancer cells. SEDS: solution-enhanced dispersion via supercritical $\mathrm{CO}_{2}, \mathrm{CM}$ : curcumin; SF: silk fibroin.

Fig. 1. Surface morphology and proposed molecular structure of CM-SF nanofibrous matrix (a) before and (b) after ethanol vapour treatment; (c) chemical composition and in vitro drug release within (d) $2 \mathrm{~h}$ and (e) 2 weeks of CM-SF nanofibrous matrix under different conditions. (supplementary Fig. S5)

Fig. 2. (a) Fluorescence images showing intracellular uptake efficiency of CM-SF nanofibrous matrix into cancer cells; (b) diagram displays the mechanism of enhanced cellular uptake efficiency. CM: curcumin; SF: silk fibroin.

Fig. 3. Smart treatment of cancer cells by CM-SF nanofibrous matrix. (a) In vitro anti-cancer effect (dose-depend) on HCT116 and (b) cytotoxicity on NCM460; (c) in vitro anti-cancer effect (time-depend) on HCT116 cells and (d) cytotoxicity on 
NCM460 within 6 days; (e) diagram illustrates smart treatment concentration range (STCR) of CM-SF nanofibrous matrix. CM: curcumin, SF: silk fibroin. The results are shown in mean $\pm \mathrm{SD}, \mathrm{n}=6$. The statistical significance is expressed as $* * * \mathrm{p}<0.001$, $* * \mathrm{p}<0.01$.

Fig. 4. (a) Qualitative cell cycle and (b) apoptotic progression of HCT116 cells in response to control, 5-Fu, and $\mathrm{CM}-\mathrm{SF}$ nanofibrous matrices after ethanol vapour treatment $\left(25^{\circ} \mathrm{C}, 6 \mathrm{~h}\right.$ and $37^{\circ} \mathrm{C}, 12 \mathrm{~h}$, respectively) for $24 \mathrm{~h}$ and $48 \mathrm{~h}$. Quadrant Q1, Q2, Q3 and Q4 reflect necrosis, late apoptosis, alive and early apoptosis, respectively. (c) Quantitative analysis of cell cycle and (d) FACS distributions (\%) of apoptotic HCT-116 cells in response to different groups at $24 \mathrm{~h}$ and $48 \mathrm{~h}$. Total apoptosis include late apoptosis plus early apoptosis. All the data was obtained from at least three independent experiments. The statistical significance is expressed as ***p $<0.001, * * \mathrm{p}<0.01, * \mathrm{p}<0.05$.

Fig. 5. In vivo investigation of tumour inhibition effects of the CM-SF nanofibrous matrices: (a) implantation process of CM-SF nanofibrous matrix into experimental mice; (b) tumour growth curves and (c) body weight change ratios of mice treated by different groups during the experimental periods; (d) tumour weight; (e) macroscopic images and (f) solid tumour histopathology of exposed tumours in experimental mice treated with 5-Fu (at LD50 level), SF control (implantation), original CM (orally administrated) and CM-SF nanofibrous matrices after ethanol vapour treatment $\left(25^{\circ} \mathrm{C}\right.$, $6 \mathrm{~h}$ and $37^{\circ} \mathrm{C}, 12 \mathrm{~h}$, respectively. $10 \mathrm{mg} /$ mice) after 12 days observation. CM: 
curcumin; SF: silk fibroin; The statistical significance is expressed as **p $<0.01,{ }^{*} \mathrm{p}$ $<0.05$. 